\title{
ANALISIS PENGARUH MODIFIKASI STRUKTUR BETON BERTULANG BANGUNAN ATAS TERHADAP DAYA DUKUNG DAN PENURUNAN PONDASI TIANG PANCANG PADA GEDUNG FISIPOL ULM BANJARMASIN
}

\author{
Hari Nukta Ramadani \\ Engineering Planning and Construction PT. Adaro Energy Tbk \\ Alumni Prodi (S-1) Teknik Sipil, Fakultas Teknik, Uniska MAB \\ E-mail: harinukta@gmail.com/HP.+6285332581740
}

\begin{abstract}
ABSTRAK
Desain struktur pondasi bawah pada proyek gedung kuliah baru Fakultas Ilmu Sosial dan Ilmu Politik (FISIPOL) Universitas Lambung Mangkurat Banjarmasin dinilai terlalu boros dari segi kapasitas daya dukungnya karena hanya digunakan untuk menahan beban bangunan atas setinggi 4 lantai saja. Hal tersebut memunculkan keingintahuan terkait kemampuan struktur bawah bangunan tersebut. Maka dari itu, penulis bermaksud untuk merencanakan ulang dengan modifikasi penambahan 1 lantai struktur bangunan atas, kemudian menganalisis pengaruh modifikasi tersebut terhadap kemampuan struktur bangunan bawah eksisting yang ditinjau dari kapasitas daya dukung dan penurunan pondasi tiang. Analisis struktur bangunan atas menggunakan program aplikasi komputer yaitu STAAD Pro V8i, untuk analisis kapasitas daya dukung pondasi tiang pancang dilakukan berdasarkan data N-SPT menurut Meyerhoff dan analisis penurunan tiang menggunakan Metode Poulos-Davis. Dari hasil analisis diperoleh nilai pembebanan arah vertikal ( $\mathrm{Pu}_{\text {Maksimum}}$ ) bangunan eksisting sebesar 321,829 Tonf, sedangkan bangunan modifikasi sebesar 408,506 Tonf. Hasil analisis kapasitas daya dukung pondasi tiang pancang diperoleh nilai Daya Dukung Tiang Kelompok (Qu $\mathrm{U}_{\text {Kelompok})}$ sebesar 1558,874 Ton. Hasil analisis penurunan tiang untuk bangunan eksisting penurunan tiang kelompok $\left(\mathrm{S}_{\mathrm{g}}\right)$ sebesar $28,2 \mathrm{~mm}$, sedangkan untuk bangunan modifikasi diperoleh penurunan tiang kelompok $\left(\mathrm{S}_{\mathrm{g}}\right)$ sebesar $35,8 \mathrm{~mm}$, meskipun relatif terjadi pertambahan nilai, penurunan tiang tersebut masih lebih kecil dari $40 \mathrm{~mm}\left(\mathrm{~S}_{\mathrm{izin}}\right)$ yang berarti aman. Sedangkan untuk Faktor Keamanan (FK), yang awalnya pada bangunan eksisting memiliki nilai FK sebesar 4,84, kemudian pada bangunan modifikasi nilai FK berkurang menjadi 3,81 , tetapi meskipun terjadi pengurangan, nilai FK bangunan modifikasi tersebut masih lebih besar dari 3 (FK yang disarankan) sehingga dapat dikatakan struktur bangunan bawah eksisting masih mampu menahan beban struktur bangunan atas meskipun dengan adanya tambahan 1 lantai menjadi 5 lantai.
\end{abstract}

Kata Kunci: Modifikasi Struktur, Daya Dukung, Penurunan, Tiang Pancang, FISIPOL ULM. 


\begin{abstract}
The design of the lower foundation structure of the new lecture building project of the Faculty of Social and Political Sciences (FISIPOL) Lambung Mangkurat University in Banjarmasin is considered too wasteful in terms of carrying capacity because it is only used to hold the burden of buildings up to 4 floors high. This raises curiosity related to the ability of the structure under the building. Therefore, the authors intend to re-plan with the modification of the addition of 1 storey structure of the upper building, then analyze the effect of these modifications on the ability of the existing structure of the lower building in terms of carrying capacity and reduction of the pile foundation. Analysis of the structure of the building using a computer application program namely STAAD Pro V8i, for the analysis of the carrying capacity of the pile foundation carried out based on $N$-SPT data according to Meyerhoff and analysis of the reduction of the pile using the Poulos-Davis Method. From the analysis results obtained the value of the vertical loading (PuMaximum) of the existing building is 321,829 Tonf, while the modified building is 408,506 Tonf. The results of the analysis of the carrying capacity of the pile foundation found the value of the carrying capacity of the Pole Group (QuGroup) of 1558,874 tons. The results of the analysis of the decrease in piles for the existing building decrease in group piles $(S g)$ by $28.2 \mathrm{~mm}$, while for the modification buildings obtained a decrease in pile groups ( $S g$ ) by $35.8 \mathrm{~mm}$, although the relative increase in value occurs, the decline in the pile is still smaller than $40 \mathrm{~mm}$ (Sizin) which means safe. As for the Safety Factor (FK), which initially had an FK value of 4.84, then the FK modification building was reduced to 3.81, but despite the reduction, the FK modification building value was still greater than 3 (FK recommended) so that it can be said that the existing lower structure of the building is still able to withstand the burden of the upper structure despite the addition of 1 floor to 5 floors.
\end{abstract}

Keywords: Structure Modification, Carrying Capacity, Decline, Pile, ULM FISIPOL

\title{
Latar Belakang
}

\section{PENDAHULUAN}

Pembangunan gedung kuliah baru Fakultas Ilmu Sosial dan Ilmu Politik (FISIPOL) merupakan salah satu strategi yang dilakukan Universitas Lambung Mangkurat selaku lembaga pendidikan dalam meningkatkan kualitas pelayanan dan fasilitas bagi mahasiswanya.

Berdasarkan pengalaman penulis ketika mengikuti Praktik Kerja Lapangan pada Proyek Pembangunan Gedung FISIPOL ULM Banjarmasin. Sempat terjadi diskusi dengan beberapa pelaksana dan pekerja di lapangan, yang mana membahas mengenai kurang maksimalnya perencanaan gedung tersebut. Hal ini didasari beberapa pengamatan para pekerja mengenai dimensi dan mutu bahan yang digunakan. Dimensi pada struktur pondasi bawah dinilai terlalu boros dari segi kapasitas daya dukungnya karena hanya digunakan untuk menahan beban 
bangunan atas setinggi 4 lantai saja.

Pondasi yang digunakan pada Gedung FISIPOL adalah tiang pancang beton pracetak (precast concrete pile). Tiang pancang digunakan sebagai pondasi pada suatu bangunan ialah apabila tanah dasar di bawah bangunan tersebut tidak memiliki daya dukung yang cukup untuk memikul beban bangunan atas atau juga apabila letak lapisan tanah keras yang sangat dalam. Maka dari itu, sangat perlu adanya informasi terkait penyelidikan tanah baik untuk mengetahui letak lapisan tanah keras, serta mengetahui daya dukung, penurunan dan sebagainya (Hayati dan Iskandar, 2017).

Dari uraian latar belakang di atas, memunculkan ide bagi penulis untuk melakukan penelitian guna menjawab rasa keingintahuan mengenai kemampuan struktur atas dan struktur bawah bangunan tersebut. Maka dari itu, penulis bermaksud untuk merencanakan ulang struktur beton bertulang bangunan atas Gedung FISIPOL ULM Banjarmasin, kemudian menganalisis pengaruh modifikasi tersebut terhadap kemampuan struktur bangunan bawah eksisting yang ditinjau dari kapasitas daya dukung dan penurunan pondasi tiang pancang.

\section{Tujuan Penelitian}

1. Merencanakan modifikasi struktur bangunan atas dengan penambahan 1 lantai.

2. Mengetahui analisis pembebanan struktur arah vertikal menggunakan aplikasi program STAAD Pro V8i.

3. Mengetahui analisis kapasitas daya dukung pondasi tiang pancang.

4. Mengetahui analisis penurunan pondasi tiang pancang.

5. Mengetahui pengaruh modifikasi struktur bangunan atas terhadap kapasitas daya dukung struktur bangunan bawah eksisting.

\section{TINJAUAN PUSTAKA}

Perkembangan dunia konstruksi dewasa ini condong berorientasi pada pengembangan konstruksi yang lebih ekonomis dengan teknologi perencanaan dan penggunaan bahan berkekuatan tinggi. Setiap konstruksi yang direkayasa dengan bertumpu pada tanah harus didukung oleh pondasi (Bowles, 1991).

Pondasi merupakan bagian dari sistem rekayasa yang meneruskan beban dari bangunan (struktur atas) ke pondasi (struktur bawah) melalui bidang antara interface/tanah) ke dalam tanah dan dasar batuan yang terletak di bawahnya (Braja M. Das, 1941). Dalam pemilihan jenis pondasi yang digunakan harus didasarkan pada fungsi bangunan atas (upper structure), besarnya beban dan beratnya bangunan atas, keadaan tanah dimana bangunan didirikan, serta tinjauan dari segi ekonominya (Andayana, 2016).

Daya dukung tiang ialah kombinasi antara tahanan selimut dan tahanan ujung tiang untuk mendukung konstruksi, khususnya apabila lapisan tanah kuat terletak sangat dalam. Daya dukung tiang juga diperlukan untuk mendukung bangunan yang menahan gaya angkat ke atas, khususnya untuk bangunan bertingkat yang dipengaruhi gaya atau momen guling akibat beban angin (Hardiyatmo, 2002). 


\section{METODE PENELITIAN}

Metode penelitian yang digunakan dalam penyusunan skripsi ini ialah metode eksperimental yaitu dengan melakukan observasi terhadap suatu kondisi buatan (manipulasi terhadap objek penelitian) yang kemudian hasilnya akan dibandingkan dengan suatu kontrol. Tujuan dari penelitian eksperimental ialah untuk menguji hipotesis serta untuk menemukan hubungan sebab-akibat.

Dilakukan perencanaan atau desain ulang terhadap struktur bangunan eksisting, dengan modifikasi yaitu berupa penambahan 1 lantai dengan tanpa mengubah dimensi struktur eksisting, sehingga yang awalnya hanya memiliki ketinggian 4 lantai kemudian dimodifikasi menjadi setinggi 5 lantai. Kemudian mendefinisikan sekelompok gaya yang akan bekerja pada suatu luasan struktur sesuai dengan standar yang digunakan yaitu SNI 1727-2013.

Analisis struktur menggunakan program aplikasi komputer yaitu STAAD Pro V8i untuk mengetahui seberapa besar pembebanan oleh struktur bangunan atas yang akan diterima pondasi. Dari analisis program tersebut dapat diperoleh gaya horizontal, gaya vertikal, dan gaya momen yang terjadi. Dalam penelitian ini, gaya yang digunakan dalam analisis kapasitas daya dukung dan penurunan tiang adalah gaya vertikal maksimum sebagai beban kolom.

Dalam analisis kapasitas daya dukung pondasi tiang pancang menggunakan data N-SPT serta Metode perhitungan Meyerhoff, perhitungan nilai koreksi menggunakan rumus Skempton, dan perhitungan efisiensi tiang kelompok menggunakan rumus Converse-Labarre. Kemudian sebagai kontrol nilai kapasitas daya dukung tersebut dibandingkan terhadap hasil analisis beban struktur vertikal maksimum untuk mengetahui nilai faktor keamanannya (Safety Factor). Sedangkan, untuk analisis perhitungan nilai penurunan tiang tunggal menggunakan Metode Poulos-Davis dan analisis penurunan tiang kelompok menggunakan Metode Meyerhoff untuk mengetahui nilai penurunan maksimum yang kemudian dibandingkan dengan penurunan izin sebagai kontrol syarat aman. Tahapan penelitian tersebut sesuai dengan diagram alir pada Gambar 1 . 


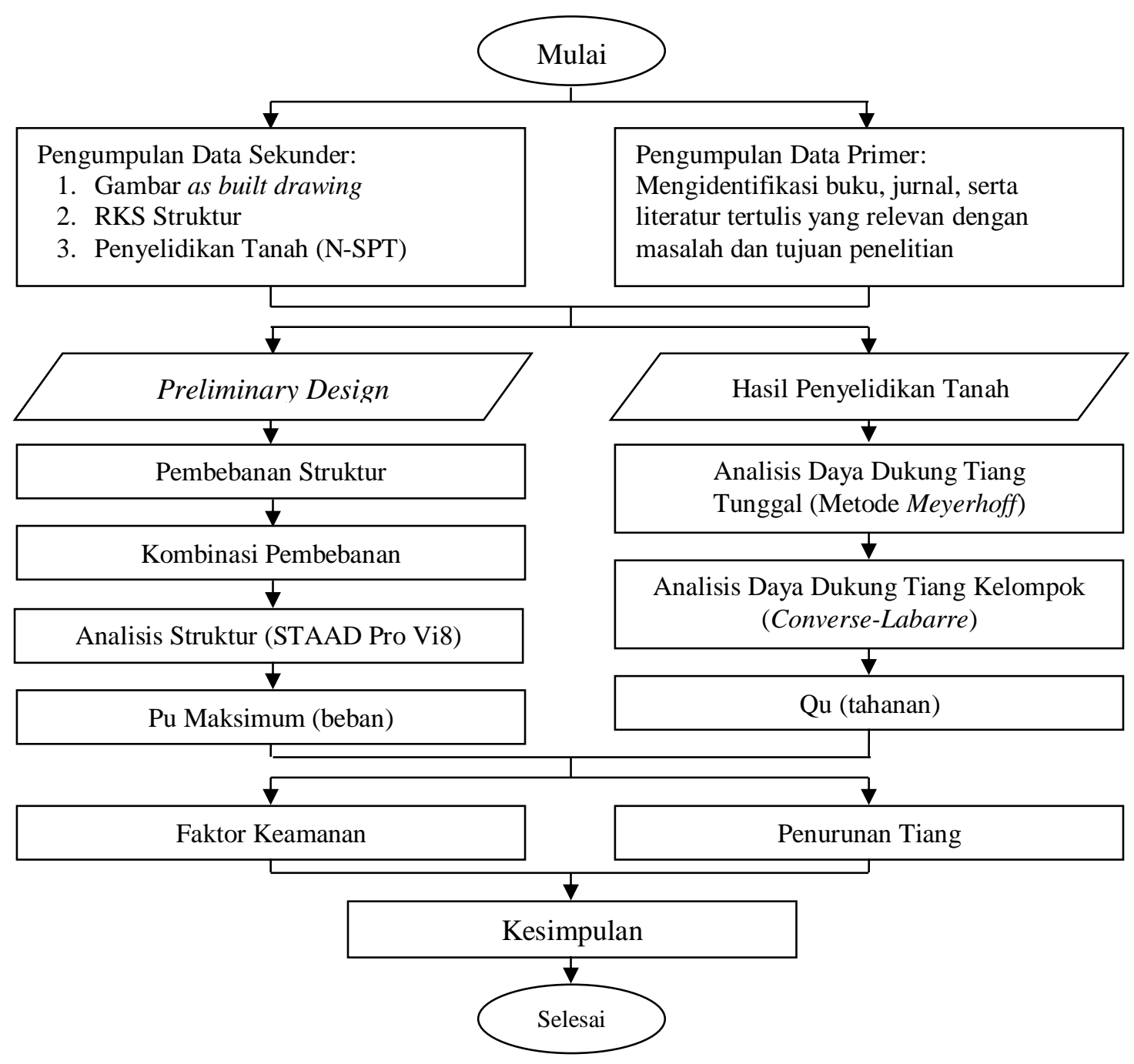

Gambar 1. Diagram Alir Penelitian

\section{HASIL DAN PEMBAHASAN}

\section{Data Teknis Material Struktur}

Kuat tekan beton $\left(f^{\prime} c\right)$ :

41,5 Mpa (untuk tiang pancang)

24,9 Mpa (untuk kolom, balok, pelat)

Tegangan leleh baja $(f y)$ :

400 Mpa (Tulangan Tarik)

240 Mpa (Tulangan Geser)

Modulus elastisitas baja (Es):

200.000 MPa 


\section{Preliminary Design}

Tabel 1. Preliminary Design Bangunan

\begin{tabular}{|c|l|c|c|c|}
\hline No & Komponen Struktur & \multicolumn{3}{|c|}{ Dimensi } \\
\cline { 3 - 5 } & & $\begin{array}{c}\text { B } \\
(\mathrm{cm})\end{array}$ & $\begin{array}{c}\text { D } \\
(\mathrm{cm})\end{array}$ & H (cm) \\
\hline 1 & Balok: & & & \\
& - MB1 & 40 & & 80 \\
& - MB2 & 40 & & 70 \\
& - MB3 & 40 & & 50 \\
& - MB4 & 40 & & 50 \\
& - MB5 & 30 & & 60 \\
& Balok Anak: & & & \\
& - SB1 & 30 & & 60 \\
& - SB2 & 30 & & 40 \\
\hline 2 & Kolom: & & & \\
& - C1 & & 80 & \\
& - C2 & & 80 & \\
& - C3 & 50 & & 50 \\
& - C4 & 30 & & 30 \\
\hline 3 & Pelat: & & & \\
& - S1 & & & 15 \\
& - S2 & & & 12 \\
& - S3 & & & 10 \\
\hline
\end{tabular}

Sumber: Proyek IDB 7 in 1 - ULM

\section{Pembebanan Struktur}

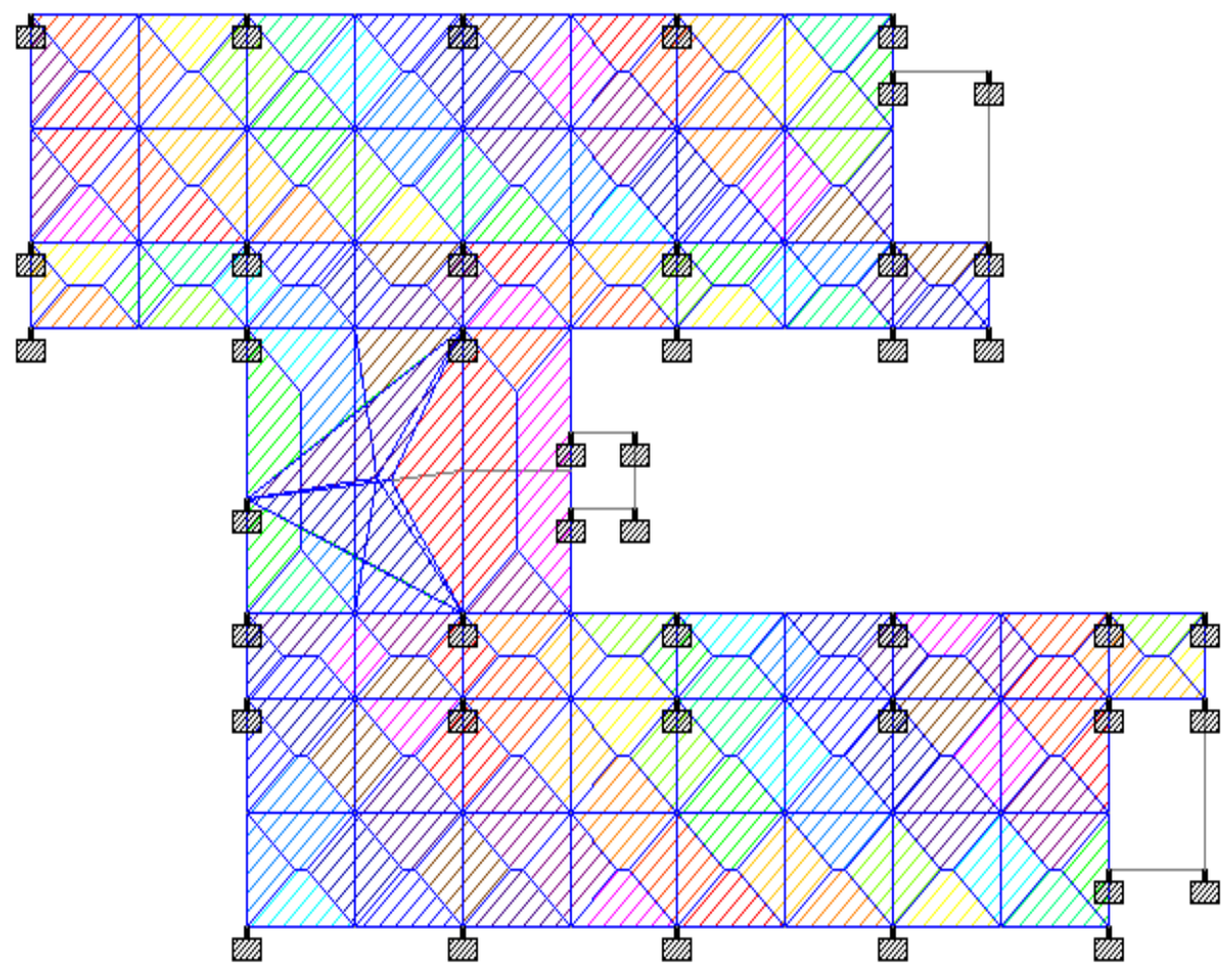

Gambar 2. Tinjauan Pemindahan Beban pada Bangunan 


\section{Analisis Daya Dukung Tiang Pancang}
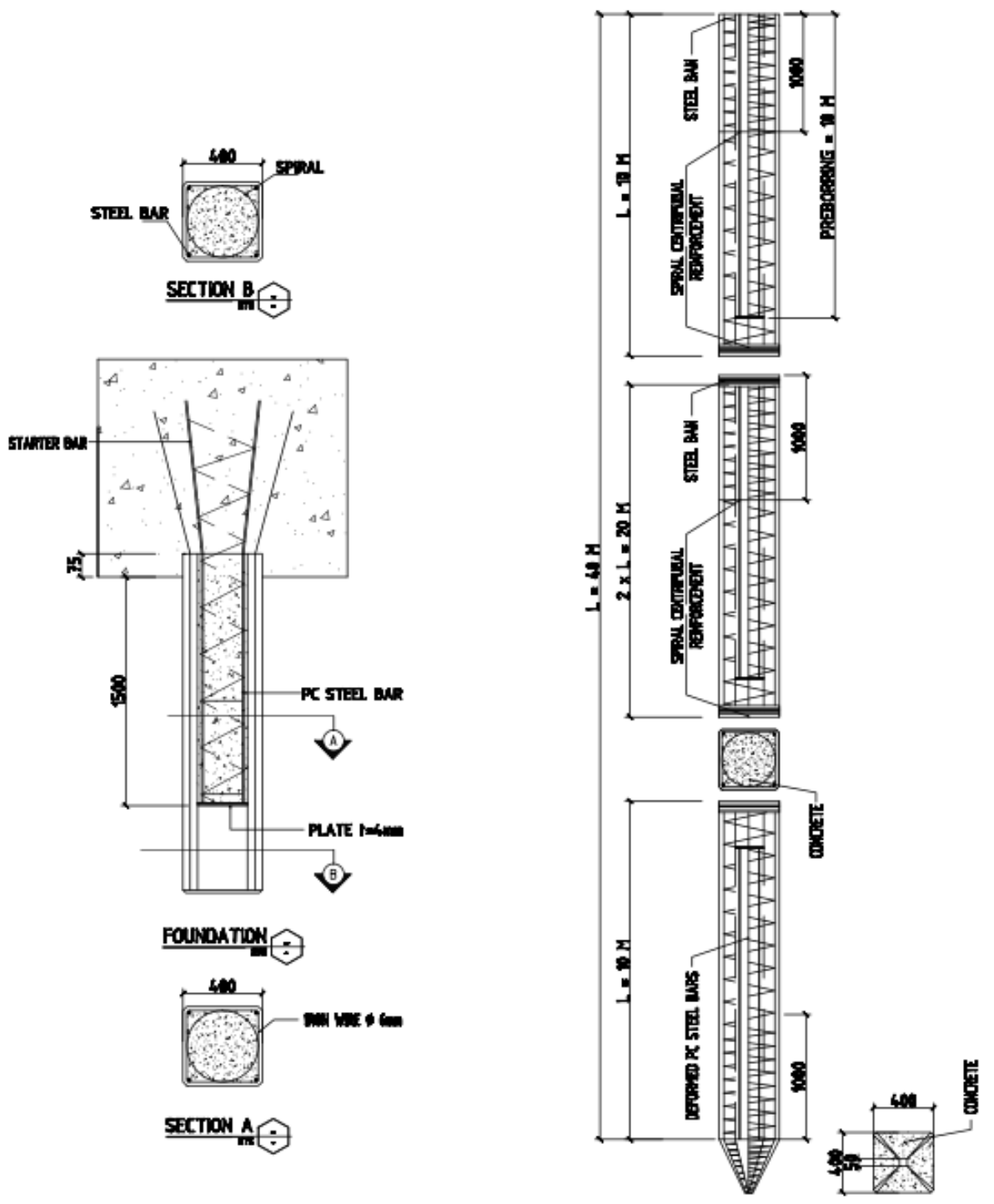

Gambar 3. Detail Tiang Pancang

Dimensi $(\mathrm{b} \times \mathrm{h}) \quad=40 \times 40 \mathrm{~cm}$

(prestress pile/persegi)

Dicoba dengan kedalaman $40 \mathrm{~m}$

Berdasarkan data N-SPT, diketahui kondisi tanah mengandung lempung cukup banyak dengan plastisitas tinggi, maka digunakan Metode Meyerhoff:

$$
\begin{aligned}
\mathrm{Qu} & =\mathrm{Qp}+\mathrm{Qs}-\mathrm{Wp} \\
& =43,92+544-(0,277 \times 40) \\
& =43,92+544-9,08 \\
& =578,84 \text { Ton }
\end{aligned}
$$




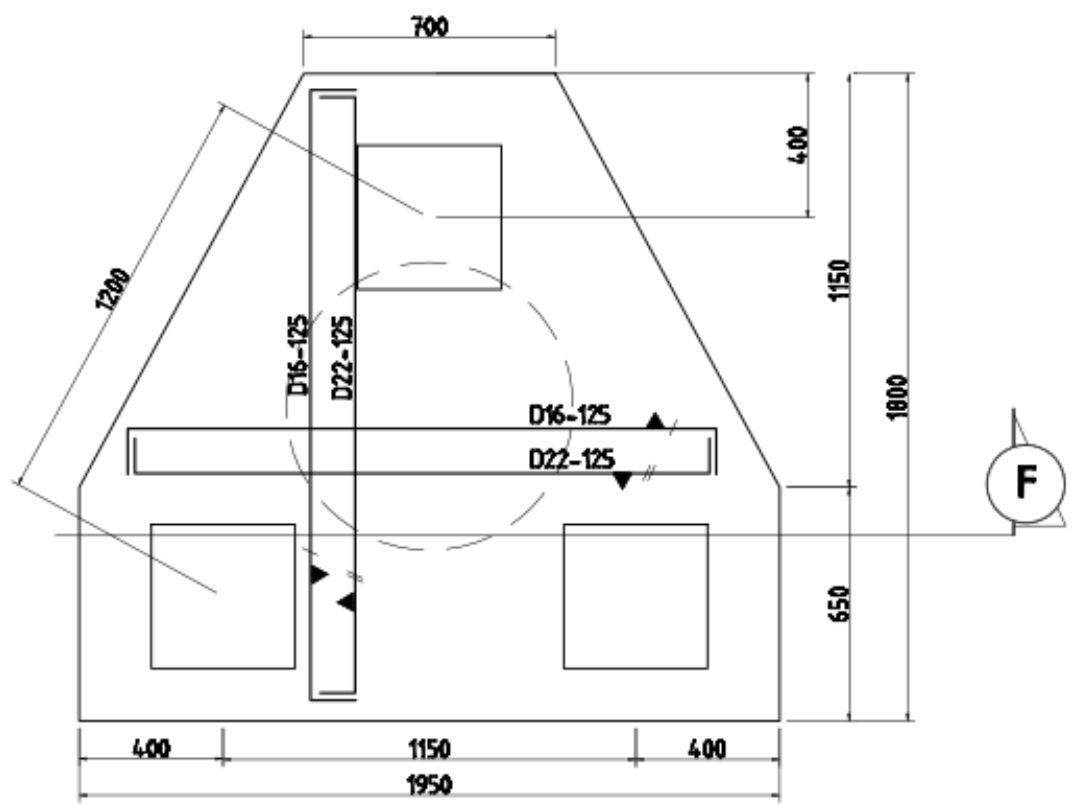

Gambar 4. Detail Pile Cap

$$
\begin{aligned}
\mathrm{E}_{\mathrm{g}} & =1-18,41^{\circ} \frac{(1-1) 2+(2-1) 1}{90 \times 2 \times 1} \\
& =1-\left(18,41^{\circ} \mathrm{x}(1 / 180)\right) \\
& =1-0,10227 \\
& =0,8977=89,77 \%
\end{aligned}
$$

$\mathrm{Qu}_{\text {kelompok }}=\mathrm{E}_{\mathrm{g}} \times \mathrm{n} \times \mathrm{Qu}$ tunggal

$$
\begin{aligned}
& =89,77 \% \text { × } 3 \text { x } 578,84 \\
& =\mathbf{1 5 5 8 , 8 7 4} \text { Ton }
\end{aligned}
$$

\section{Analisis Pembebanan Struktur Bangunan Eksisting}

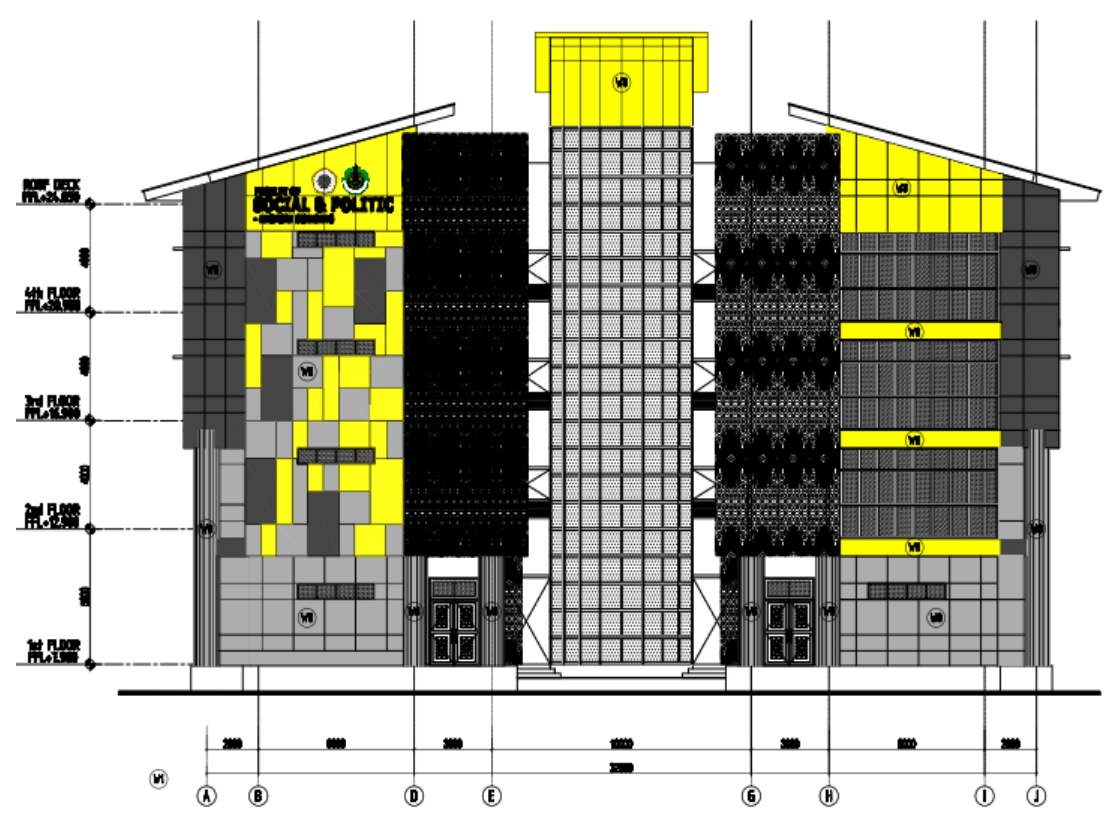

Gambar 5. Tampak Depan Gedung Eksisting 
JURNAL KACAPURI

JURNAL KEILMUAN TEKNIK SIPIL

Volume 2 Nomor 2 Edisi Desember 2019

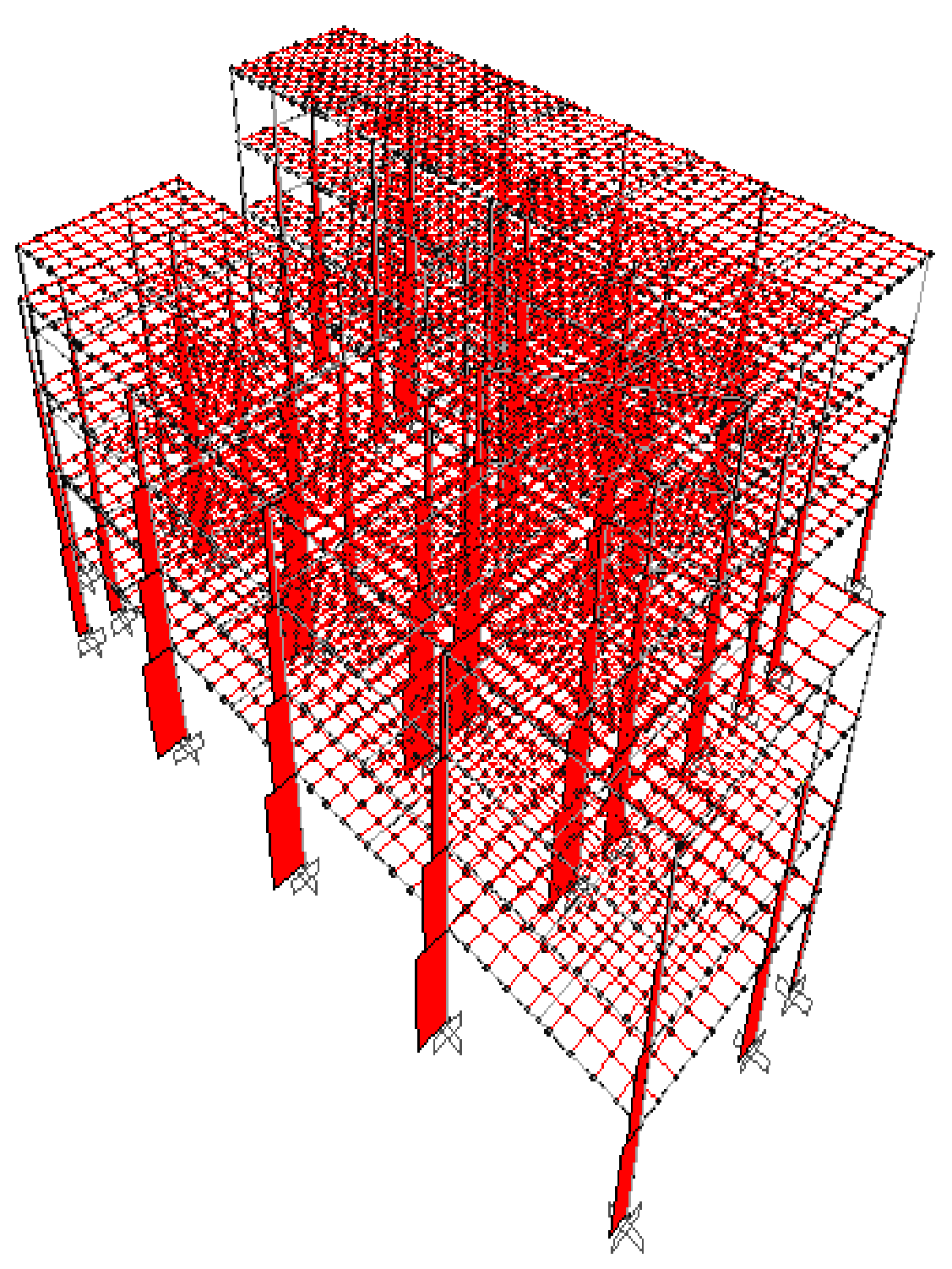

Gambar 6. Hasil Pembebanan Arah Vertikal (Eksisting)

Berdasarkan hasil analisis reaksi perletakan bangunan eksisting dengan menggunakan program STAAD Pro diketahui nilai pembebanan arah vertikal $(\mathrm{Pu}$ Maksimum) terjadi pada titik joint $17=321,829$ Ton. Pada titik tersebut menggunakan pondasi kelompok 3 tiang pancang dengan nilai daya dukung tiang kelompok $(\mathrm{Qu}$ Kelompok $)=1558,874$ Ton. Dari data tersebut dapat diketahui nilai faktor keamanannya seperti pada perhitungan berikut ini.

$$
\begin{aligned}
\mathrm{FK} & =\mathrm{Qu} / \mathrm{Pu} \\
& =1558,874 / 321,829 \\
& =\mathbf{4 , 8 4}>\mathbf{3} \rightarrow \mathbf{O K E}
\end{aligned}
$$


JURNAL KACAPURI

JURNAL KEILMUAN TEKNIK SIPIL

Volume 2 Nomor 2 Edisi Desember 2019

\section{Analisis Pembebanan Struktur Bangunan Modifikasi}
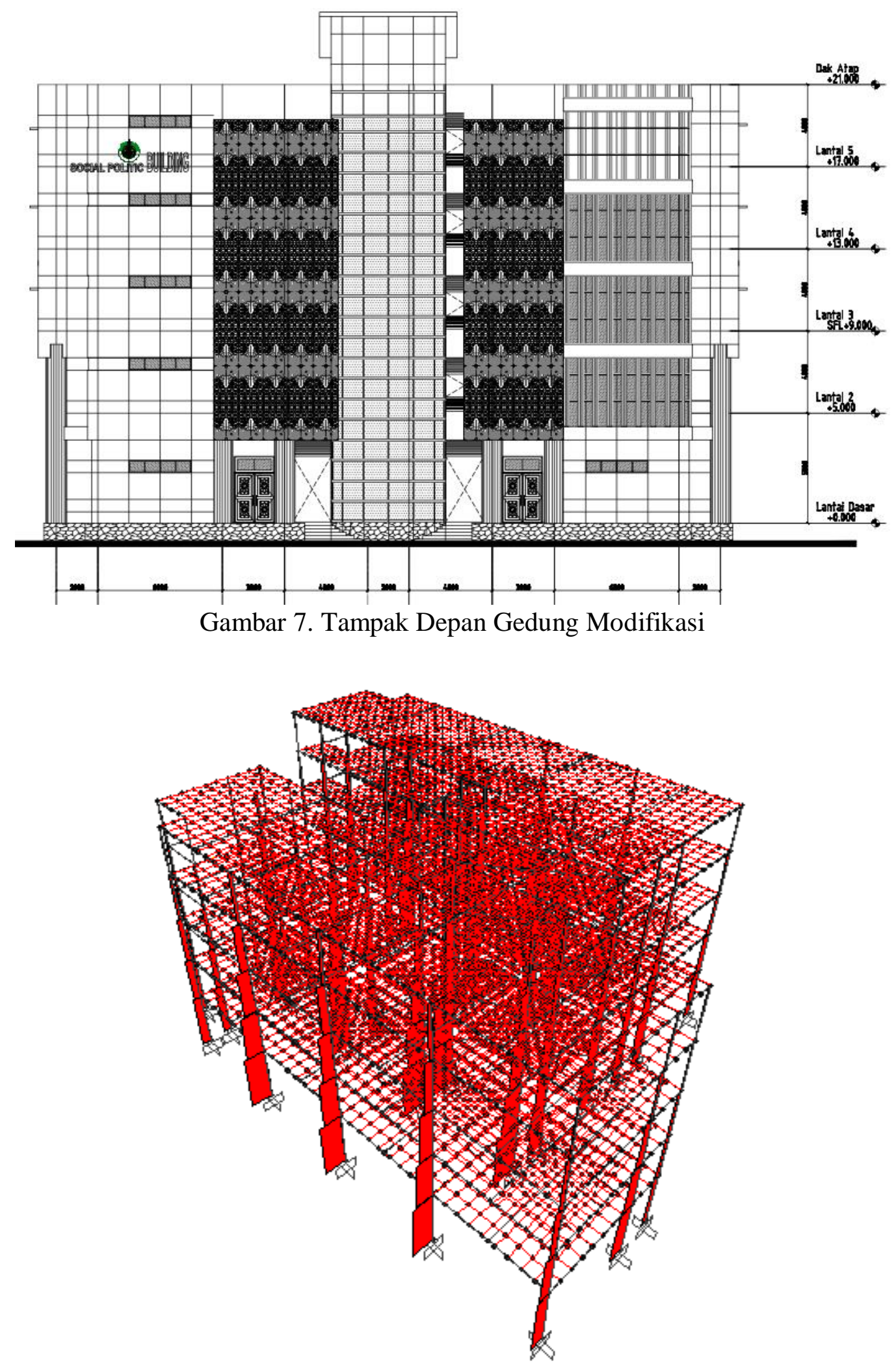

Gambar 8. Hasil Pembebanan Arah Vertikal (Modifikasi) 
Berdasarkan hasil analisis reaksi perletakan bangunan modifikasi dengan menggunakan program STAAD Pro diketahui nilai pembebanan arah vertikal $(\mathrm{Pu}$ Maksimum) terjadi pada titik joint $17=408,506$ Ton. Pada titik tersebut menggunakan pondasi kelompok 3 tiang pancang dengan nilai daya dukung tiang kelompok $(\mathrm{Qu}$ Kelompok $)=1558,874$ Ton. Dari data tersebut dapat diketahui nilai faktor keamanannya seperti pada perhitungan berikut ini.

$$
\begin{aligned}
\mathrm{FK} & =\mathrm{Qu} / \mathrm{Pu} \\
& =1558,874 / 408,506 \\
& =\mathbf{3 , 8 1}>\mathbf{3} \rightarrow \mathbf{O K E}
\end{aligned}
$$

\section{Penurunan Tiang Izin}

$$
\begin{aligned}
S_{\text {izin }} & =10 \% \cdot D \\
= & 10 \% \cdot 40 \\
= & 4 \mathrm{~cm} \\
= & \mathbf{4 0} \mathbf{~ m m}
\end{aligned}
$$

\section{Penurunan Tiang pada Bangunan Eksisting}

$$
\begin{aligned}
\mathrm{S}_{\mathrm{g}} & =\frac{2 \mathrm{q} \sqrt{\mathrm{Bg}_{\mathrm{g}}}}{\mathrm{N}} \\
& =\frac{2.9,16 \sqrt{180 \cdot 0,864}}{81} \\
& =2,82 \mathrm{~cm} \\
& =\mathbf{2 8 , 2} \mathbf{~ m m}<\mathbf{4 0} \mathbf{~ m m}\left(\mathbf{S}_{\text {izin }}\right) \rightarrow \text { OKE }
\end{aligned}
$$

\section{Penurunan Tiang pada Bangunan Modifikasi}

$$
\begin{aligned}
\mathrm{S}_{\mathrm{g}} & =\frac{2 \mathrm{q} \sqrt{\mathrm{Bg}_{\mathrm{g}}}}{\mathrm{N}} \\
& =\frac{2.11,63 \sqrt{180 \cdot 0,864}}{81} \\
& =3,58 \mathrm{~cm} \\
& =\mathbf{3 5 , 8} \mathbf{~ m m}<\mathbf{4 0} \mathbf{~ m m}\left(\mathbf{S}_{\text {izin }}\right) \rightarrow \text { OKE }
\end{aligned}
$$

\section{Kesimpulan}

\section{PENUTUP}

Berdasarkan penelitian yang telah dilakukan dapat ditarik kesimpulan:

1. Modifikasi struktur bangunan atas pada Gedung FISIPOL ULM dilakukan dengan cara menambah 1 lantai, menjadi 5 lantai, dimana tinggi lantai 1 yaitu 5 $\mathrm{m}$ dan lantai 2-5 yaitu $4 \mathrm{~m}$. Perancangan modifikasi struktur mengacu pada desain perencanaan awal Proyek IDB 7 in 1 - ULM.

2. Analisis pembebanan struktur arah vertikal menggunakan program STAAD Pro V8i, untuk bangunan eksisting diperoleh nilai $\mathrm{Pu}$ Maksimum sebesar 321,829 Tonf, sedangkan untuk bangunan modifikasi diperoleh nilai $\mathrm{Pu}$ Maksimum sebesar 408,506 Tonf. 
3. Analisis kapasitas daya dukung pondasi tiang pancang berdasarkan data NSPT, diperoleh nilai Daya Dukung Tiang Kelompok (Qu kelompok) sebesar 1558,874 Ton.

4. Analisis penurunan tiang, untuk bangunan eksisting diperoleh penurunan tiang kelompok $\left(\mathrm{S}_{\mathrm{g}}\right)$ sebesar $28,2 \mathrm{~mm}$, sedangkan untuk bangunan modifikasi diperoleh penurunan tiang kelompok $\left(\mathrm{S}_{\mathrm{g}}\right)$ sebesar $35,8 \mathrm{~mm}$, meskipun relatif terjadi pertambahan nilai, penurunan tiang tersebut masih lebih kecil dari 40 $\mathrm{mm}\left(\mathrm{S}_{\mathrm{izin}}\right)$ yang berarti aman.

5. Modifikasi struktur bangunan atas pada gedung FISIPOL ULM berpengaruh pada nilai Faktor Keamanan (FK), yang awalnya pada bangunan eksisting memiliki nilai FK sebesar 4,84, kemudian pada bangunan modifikasi nilai FK berkurang menjadi 3,81 , tetapi meskipun terjadi pengurangan, nilai FK bangunan modifikasi tersebut masih lebih besar dari 3 (FK yang disarankan) sehingga dapat dikatakan struktur bangunan bawah eksisting masih mampu menahan beban struktur bangunan atas meskipun dengan adanya tambahan 1 lantai menjadi 5 lantai.

\section{Saran-saran}

Beberapa saran yang dapat penulis berikan, sebagai berikut:

1. Analisis struktur menggunakan program STAAD Pro memerlukan ketelitian dan kesabaran yang tinggi, khususnya jika struktur gedung yang dirancang memiliki detail yang rumit seperti Gedung FISIPOL ini, tetapi akan lebih mudah dalam permodelannya jika menggunakan program SAP 2000.

2. Untuk analisis kapasitas daya dukung dan penurunan pada penelitian selanjutnya disarankan untuk dapat menggunakan beberapa metode sebagai pembanding agar nantinya dapat diperoleh nilai daya dukung dan penurunan yang mendekati keadaan aslinya di lapangan.

\section{Ucapan Terimakasih}

Penulis mengucapkan terimakasih kepada kawan-kawan dan rekan sejawat di Program Studi (S-1) Teknik Sipil, Fakultas Teknik, Universitas Islam Kalimantan Muhammad Arsyad Al Banjari serta semua pihak yang telah banyak membantu kelancaran dan selesainya penelitian ini.

\section{DAFTAR PUSTAKA}

Alkaff, M. Firdaus. 2006. STAAD 2004 untuk Tingkat Menengah. Palembang: Penerbit Maxikom. ISBN: 979-3767-58-8.

Badan Standarisasi Nasional. 2012. SNI-1726-2012 Tata Cara Perencanaan Ketahanan Gempa untuk Struktur Bangunan Gedung dan Non Gedung. Jakarta: Badan Standarisasi Nasional.

Badan Standarisasi Nasional. 2013. SNI-1727-2013 Beban Minimum untuk Perancangan Bangunan Gedung dan Struktur Lain. Jakarta: Badan Standarisasi Nasional.

Bowles, J. E. 1991. Analisa dan Desain Pondasi, Edisi keempat Jilid 1. Jakarta: Erlangga. 
Bowles, J. E. 1993. Analisa dan Desain Pondasi, Edisi keempat Jilid 2. Jakarta: Erlangga.

Coduto, Donald P. 1994. Foundation Design Principles and Practices, New Jersey: Prentice-Hall.

Departemen Pekerjaan Umum. 1987. Pedoman Perencanaan Pembebanan untuk Rumah dan Gedung (PPPURG 1987). Jakarta: Badan Standarisasi Nasional.

Febryanti, Fitri. 2018. Analisis Kapasitas Daya Dukung Pondasi Tiang Pancang Dengan Pembebanan Vertikal Menggunakan Program STAAD Pro V8i. Skripsi. Fakultas Teknik. Universitas Islam Kalimantan MAB: Banjarmasin.

Hardiyatmo, H. C. 2015. Analisis dan Perencanaan Fondasi II. Yogyakarta: Gadjah Mada University Press.

Hayati, Titi dan Iskandar, Rudi. 2017. Perbandingan Nilai Daya Dukung dan Penurunan Pondasi Tiang Pancang Berdiameter $60 \mathrm{Cm}$ Pada Titik Bore Hole I Dengan Metode Analitis dan Metode Elemen Hingga (Studi Kasus: Proyek Skyview Apartment Setiabudi). Departemen Teknik Sipil Universitas Sumatera Utara.

Hidayat, Wismar. 2018. Perencanaan Struktur Beton Bertulang Menurut SNI 2013 Pada Fakultas Ilmu Sosial dan Ilmu Politik ULM. Skripsi. Universitas Lambung Mangkurat: Banjarmasin.

Irfan, Andy Rosyulianta. 2015. Perencanaan Ulang Gedung Rumah Sakit An-Nur Yogyakarta Dengan Beton. Skripsi. Fakultas Teknik. Universitas Muhammadiyah Surakarta: Solo.

Marbun, Boycke. 2009. Analisa Penurunan Elastis Pondasi Tiang Pancang Proyek pembangunan Rusunawa Medan Area. Skripsi. Fakultas Teknik. Universitas Sumatera Utara: Medan.

Meyerhof, GG. 1976. Bearing Capacity and Settlement of Pile Foundations. ASCE Journal of Geotechnical Eng. Div. Vol 5, No 4, pp. 225-224.

Poulos, H. G. \& Davis, E. H. 1968. The Settlement Behaviour of Single Axially Loaded Incompressible Piles and Piers. Geotechnique.

PT. Wijaya Karya (Persero) Tbk. 2016. Dokumen Kontrak Proyek IDB 7 in 1 ULM (Pembangunan Gedung Baru dan Infrastruktur Universitas Lambung Mangkurat). Banjarmasin.

Pusat Studi Gempa Nasional. 2017. Peta Sumber dan Bahaya Gempa Indonesia Tahun 2017. Bandung: Pusat Penelitian dan Pengembangan Perumahan dan Permukiman Badan Penelitian dan Pengembangan Kementerian Pekerjaan Umum dan Perumahan Rakyat.

Sosrodarsono, S. dan Nakazawa, K. 1983. Mekanika Tanah dan Teknik Pondasi. PT Pradya Paramita, Jakarta.

Terzaghi, K. 1995. Evaluation Of Coeffcient Of Subgrade Reaction. Geotechnique, Vol 5. No 4 pp. 297-326.

Thomlinson, MJ. (1977; 1944). Pile Design and Construction Practice. The Garden City Press Limited, Lechworth, Hertfordshire SG6 1JS. 